ZOOLOGIA 30 (3): 343-345, June, 2013

http://dx.doi.org/10.1590/S1984-46702013000300014

\title{
A new species of Seira (Collembola: Entomobryidae) from the state of Paraíba, Brazil
}

\author{
Nerivânia Nunes Godeiro ${ }^{1,3} \&$ Bruno Cavalcante Bellini ${ }^{1,2}$
}

\author{
1 Programa de Pós-graduação em Sistemática e Evolução, Centro de Biociências, Universidade Federal do Rio Grande do \\ Norte. Campus Universitário Lagoa Nova, 59072-970 Natal, RN, Brazil. \\ 2 Departamento de Botânica, Ecologia e Zoologia, Centro de Biociências, Universidade Federal do Rio Grande do Norte. \\ 59072-970 Natal, RN, Brazil. \\ ${ }^{3}$ Corresponding author. E-mail: nerivania@gmail.com
}

\begin{abstract}
A new species of Seira Lubbock, 1869 is described and illustrated. Seira glabra sp. nov. is the second species described from the municipality of Areia (Caatinga biome) and the seventh from the state of Paraíba, Brazil. Compared with other species of the genus, Seira glabra sp. nov. has some remarkable reductions on dorsal chaetotaxy, specially on the methatorax and first abdominal segment. The most similar species to S. glabra sp. nov. is Seira praiana. Both lack macrochaetae on the first abdominal segment.
\end{abstract}

KEY WORDS. Caatinga; chaetotaxy; entomobryomorpha; Seirini; taxonomy.

Seira Lubbock, 1869 (Entomobryinae: Seirini) comprises approximately 200 described species distributed worldwide, 23 of which have been recorded from Brazil. The Brazilian fauna of this genus is certainly poorly known, considering the large number of morphotypes yet to be described (ABRANTEs et al. 2010, 2012, Bellini et al. 2010, Beluini \& Zeppelini 2011, Bellinger et al. 1996-2013). The fauna of northeastern Brazil, most particularly in the state of Paraíba is very rich in species of Seira, but only less than $10 \%$ of the state's territory has been sampled (BeLLin \& ZepPeLIN 2009). The municipality of Areia in the state of Paraíba, houses an important conservation unit inside the Caatinga phytogeographic domain, called "Mata do Pau-Ferro", where a "Brejo de altitude" can be found. Compared with other semi-arid areas inside Caatinga, "brejos" have privileged conditions, with higher total amounts of soil moisture and air humidity, cooler temperatures and a taller vegetation cover (Lima 1966). "Mata do Pau-Ferro" is one of the largest remaining areas of "Brejo" in Paraíba, with 600 hectares and is located at altitudes ranging from 400 and $600 \mathrm{~m}$ a.s.l. (BARBOSA et al. 2004).

Herein we describe a new species of Seira from "Mata do Pau-Ferro". This species represents the seventh record of the genus from Paraíba.

\section{MATERIAL AND METHODS}

The specimens were collected in November 2011, during the dry season, using pitfall traps and entomological aspirators, directly from areas where the vegetation cover is tall and litter is present. The climate of Areia is 'As' according to Koeppen's system and the region belongs to Good's biogeo- graphic zone 27 (Good 1974, Kоттек et al. 2006). The specimens were fixed in $70 \%$ ethanol. For mounting on glass slides, specimens were cleared using hydrochloric acid and potassium dichromate, following the procedures described by ArLé \& MendonçA (1982), and Hoyer liquid was used as a semi-permanent medium. The chaetotaxy schemes follow the systems of Christiansen \& Bellinger (2000), which was modified from JacQuemart (1974), and Soto-Adames (2008).

\section{TAXONOMY}

\section{Seira glabra sp. nov.}

Figs $1-12$

Description. Total body length of holotype $2.12 \mathrm{~mm}$. Habitus typically entomobryid (Figs 1 and 2). Color of specimens in $70 \%$ ethanol pale yellow with light blue pigment covering antennae and distal femora; two dark blue spots on distal part of fourth and third abdominal segments; dark pigmentation on lateral portions of mesothorax and metathorax; dark blue pigment covering front of head and eye patches (Fig. 1). Color of mounted specimens pale yellow with dark blue pigment covering eye patches and distal femora (Fig. 2); rounded brownish scales covering Ant. (antennal segments) I and II entirely, basal halves of Ant. III and IV, head, thorax, abdomen, ventral tube, all leg segments, manubrium and dentes. Ant. IV not annulated, with single apical bulb and two types of setae: bigger multiciliated setae and smaller curved smooth setae (Fig. 3). Eye patches oval with $8+8$ ocelli, the biggest being B and smallest E (Fig. 4). Five interocular multiciliated mesochaetae (Fig. 4). Pre-labral and labral setae smooth. Labial triangle M1-2 and E multiciliated, r 


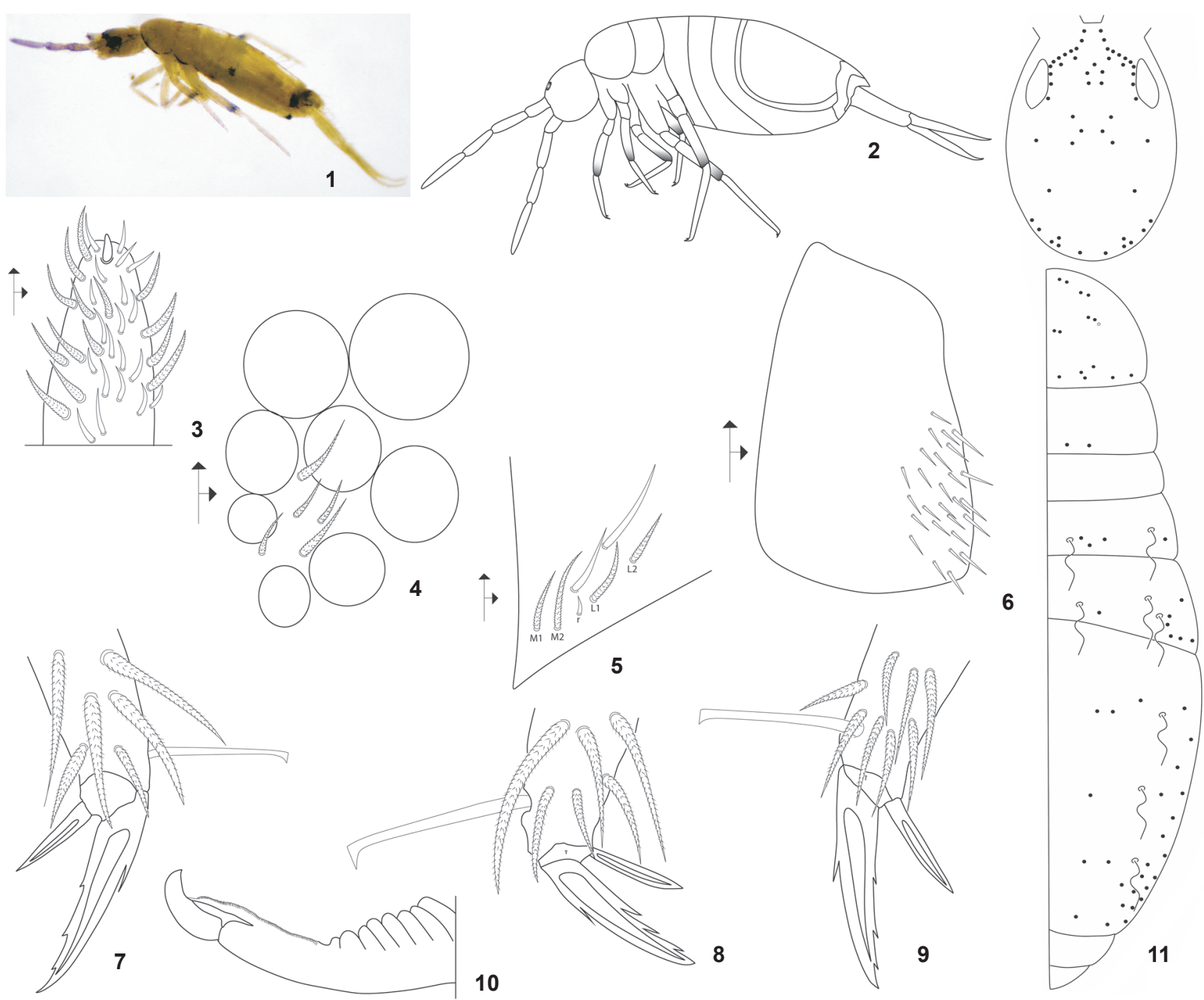

Figures 1-11. Seira glabra sp. nov.: (1) specimen in ethanol; (2) habitus; (3) apical region of Ant. IV; (4) right eye patch; (5) labial triangle setae, right side; (6) metatrochanteral organ; (7) empodial complex of leg I; (8) empodial complex of leg II; (9) empodial complex of leg III; (10) distal dens and mucro; (11) macrochaetae on head and half body, right side.

reduced (Fig. 5). Metatrochanteral organ with approximately 27 short spines (Fig. 6). All ungues with four teeth, two basal paired and two apical unpaired (Figs 7-9). Basal pair of spines of ungues of second pair of legs slightly larger than others (Fig. 8). Unguiculi acuminate (Figs 7-9). Tenent hair capitate. Ventral manubrium with $8+8$ subapical setae, spines absent. Mucro typically falcate (Fig. 10). Dorsal chaetotaxy of Abd. (abdominal segments) II-III detailed in Fig. 12. Reduction of number of macrochaetae on metathorax $(2+2)$ and absence of macrochaetae on Abd. I (Fig. 11). Dorsal macrochaetae distribution as in Fig. 11.

Material examined. Holotype male on slide, BraziL, Paraíba: Municipality of Areia (Mata do Pau-Ferro), 24-27-xi2011, B.C. Bellini leg. Paratypes: 1 male and 1 female on slides, same data as holotype. Type material deposited at Collembola Collection of Museu Nacional/UFRJ, Rio de Janeiro, number $2416 \mathrm{CM} / \mathrm{MNRJ}$.

Etymology. "Glabra" means hairless, an allusion to the reduction of chaetotaxy of the metathorax and first abdominal segment of the new species.

Remarks. Seira glabra sp. nov. shows many morphological resemblances to Seira praiana Bellini, Fernandes \& Zeppelini, 2010, described from "Restinga de Marambaia", state of Rio de Janeiro. Although inhabiting different domains (Atlantic Forest and Caatinga, respectively), both species are similar in the cephalic and antennal color patterns and in the body chaetotaxy. Seira glabra sp. nov. and S. praiana are similar due to the lack of 


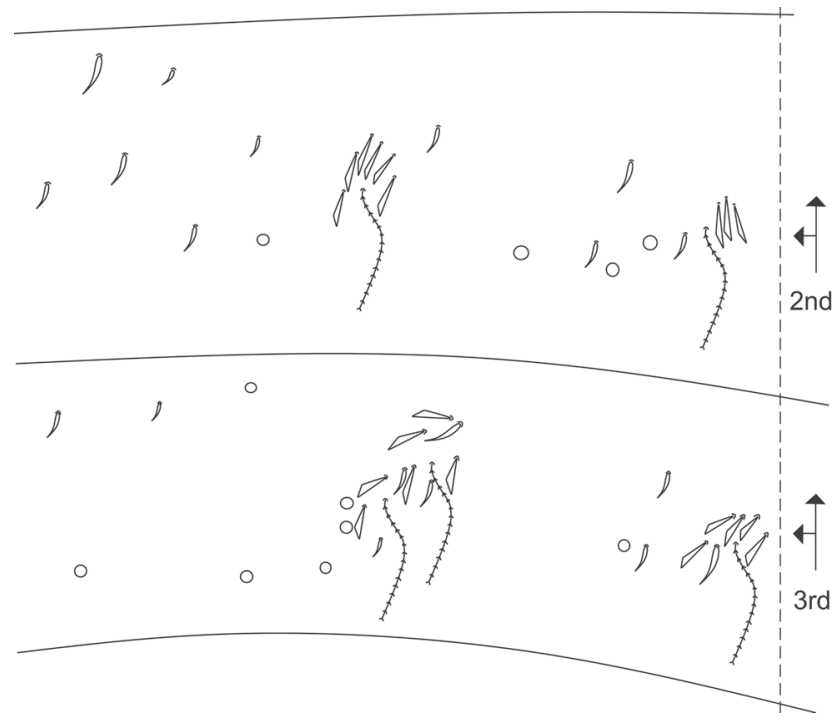

Figure 12. Detailed dorsal chaetotaxy of second and third abdominal segments of Seira glabra sp. nov. (left side).

macrochaetae on Abd. I, cephalic regions 2, 3 and 4, regions 1 and $3 \mathrm{~A}$ of the mesothorax, region $\mathrm{A}$ of $\mathrm{Abd}$. II and region $\mathrm{A}$ of Abd. III. These species also have acuminate unguiculus, single apical bulb and Ant. IV without annulations. Seira glabra sp. nov. can be readily distinguished from $S$. praiana by the cephalic region 1 with 11 macrochaetae, region 5 with two macrochaetae and region 6 with six macrochaetae, whereas in S. praiana these regions have eight, four and four macrochaetae, respectively. The new species has two macrochaetae on the region 2 of mesothorax, whereas $S$. praiana has only one. Two macrochaetae are observed on the metathorax, whereas $S$. praiana has three. Finally, six macrochaetae are found on the region B of the Abd. III, whereas $S$. praiana has three.

\section{ACKNOWLEDGMENTS}

The junior author is granted by Conselho Nacional de Desenvolvimento Científico e Tecnológico (CNPq)/Programa de Pesquisa em Biodiversidade - Invertebrados (PPBio)/Próreitoria de Pesquisa - Universidade Federal do Rio Grande do Norte (PROPESQ - UFRN).

\section{LITERATURE CITED}

Abrantes, E.A.; B.C. Bellini; A.N. Bernardo; L.H. Fernandes; M.C. Mendonça; E.P. Oliveira; G.C. Queiroz; K.D. Sautter; T.C. Silveira
\& D. Zeppelini. 2010. Synthesis on Brazilian Collembola: an update to the species list. Zootaxa 2388: 1-22.

Abrantes, E.A.; B.C. Bellini; A.N. Bernardo; L.H. Fernandes; M.C. Mendonça; E.P. Oliveira; G.C. Queiroz; K.D. Sautter; T.C. Silveira \& D. Zeppelini. 2012. Errata Corrigenda and update for the "Synthesis of Brazilian Collembola: an update to the species list." Abrantes et al. (2010), Zootaxa 2388: 122. Zootaxa 3168: 1-21.

Arlé, R. \& C. Mendonça. 1982. Estudo preliminar das espécies de Dicranocentrus Schött, 1893, ocorrentes no Parque Nacional da Tijuca, Rio de Janeiro (Collembola). Revista Brasileira de Biologia 42 (1): 41-49.

Barbosa, M.R.V.; M.F. Agra; E.V.S.B. Sampaio; J.P. Cunha \& L.A. Andrade. 2004. Diversidade florística na Mata do Pau-Ferro, Areia, Paraíba, p. 111-122. In: K.C. PôrTO; J.P. CABRAL \& M. Tabarelli (Eds). Brejos de altitude em Pernambuco e Paraíba: história natural, ecologia e conservação. Brasília, Ministério do Meio Ambiente, 324p.

Bellinger, P.F.; K.A. Christiansen \& F. Janssens. 2013. Checklist of the Collembola of the World. Available online at: http:// www.collembola.org [Accessed: 15/I/2013].

Bellini, B.C. \& D. Zeppelini. 2009. Registros da fauna de Collembola (Arthropoda, Hexapoda) no Estado da Paraíba, Brasil. Revista Brasileira de Entomologia 53: 386-390.

Bellini, B.C.; L.H. Fernandes \& D. Zeppelini. 2010. Two new species of Seira (Collembola, Entomobryidae) from Brazilian coast. Zootaxa 2448: 53-60.

Bellini, B.C. \& D. Zeppelini. 2011. A new species of Seira (Collembola: Entomobryidae: Seirini) from the Northeastern Brazilian coastal region. Zoologia 28: 403-406.

Christiansen, K. \& P. Bellinger. 2000. A survey of the genus Seira (Collembola: Entomobryidae) in the Americas. Caribbean Journal of Science 36: 39-75.

GooD, R. 1974. The geography of flowering plants. London, Longman Group, 574p.

JACQUemart, S. 1974. Resultats de la Mission Anthropologique Belge au Niger. Collemboles nouveaux du Sahara. Bulletin de l'Institut Royal des Sciences Naturelles de Belgique 50 (6): 1-46.

Kottek, M.; J. Grieser; C. Beck; B. Rudolf \& F. Rubel. 2006. World Map of the Köppen-Geiger climate classification updated. Meteorologische Zeitschrift 15: 259-263.

LimA, D.A. 1966. Esboço fitoecológico de alguns "brejos" de Pernambuco. Boletim Técnico do Instituto de Pesquisas Agronômicas de Pernambuco 8: 3-9.

Soto-Adames, F.N. 2008. Postembryonic development of the dorsal chaetotaxy in Seira downlingi (Collembola, Entomobryidae), with an analysis of the diagnostic and phylogenetic significance of the primary chaetotaxy in Seira. Zootaxa 1683: 1-31.

Submitted: 22.II.2013; Accepted: 02.IV.2013.

Editorial responsibility: Gabriel L.F. Mejdalani 